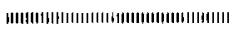

論説

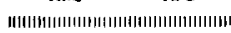

\title{
快削純チタンと快削チタン合金の被削性
}

中村貞行*

\author{
Machinability of Free-Machining Pure Titaniums and \\ Free-Machining Titanium Alloys
}

\section{Sadayuki Nakamura}

\begin{abstract}
Synopsis
Free-machining pure titaniums and free-machining titanium alloys which contain both sulfur and rare earth metals were developed, and the machinability and the mecha. nism of machinability improvement were studied. The addition of sulfur and rare earth metals produces sulfide inclusions and accelerates the concentrated slip in chip formation which reduces cutting forces and tool wear rates, and improves chip breakability.
\end{abstract}

\section{1. 緒言}

純チタンとチタン合金は優れた耐食性と高い比 強度を有して扣り, 発電や化学プラント, 航空機, ロケットなど従来の用途以外に，自動車やOA 機 器, レシャー用品などの部品にる適用されるよう になってきた。この新しい用途は従来に比べて生 産口ットが大きく，大量生産工程で製造される部 品が多い。純チタンやチタン合金は通常の鋼に比 べて切削加工が困難でありこれらの材料の被削 性改善は，大量生産工程で製造するための重要な 鍵の一つになっている。

このような背景から，純チタンとチタン合金の 被削性改善を試み，硫黄 (S)と希土類金属(REM) の複合添加が有効であることを報告しだ。 けを添加すると粒界に板状の硫化物が生成し，機 械的性質や熱間加工性が低下するが，これに

1989年 4 月 18 日 受付

*大同特殊鋼侏研究開発本部
REM を添加すると硫化物が球状になり，被削性 と機械的性質が改善される。S 含有量を増加させ ると切削抵抗が減少し，ドリル加工と超硬旋削加 工に颃ける能率が向上する。るた， S と REM を複 合添加した快削純チタンと快削チタン合金は純チ タンやチタン合金とほぼ同等の機械的性質や耐食 性を有することが明らかになった。

引き続き，快削純チタンと快削チタン合金の被 削性に関して，切削抵抗や切削温度など切削機構 に関する実験を行ったので報告する。

\section{2. 試 験 材 料}

純チタン 2 種および純チタン 4 種と $3 \mathrm{Al}-2 \mathrm{~V}$ 合 金および $6 \mathrm{Al}-4 \mathrm{~V}$ 合金に0.16 0.22\%の S と 0.46〜0.88\%の REM を添加した快削純チタンと 快削チタン合金，合計 4 種類を製造した。比較の ために各々のベース材る試験に供した。これらの 材料の化学成分を Table 1 に示す。本論説の中で は, 純チタン 2 種と 4 種をそれぞれ T2, T4 と呼 び, 3Al-2V 合金と 6Al-4V 合金を 3-2，6-4 と 呼ぶことにする。また，快削材料は材種名の末尾 
Table 1. Chemical compositions and hardness of tested materials.

\begin{tabular}{|c|c|c|c|c|c|c|c|c|c|c|}
\hline \multirow{2}{*}{ Grade } & \multicolumn{9}{|c|}{ Chemical compositions (wt\%) } & \multirow{2}{*}{$\begin{array}{c}\text { Hardness } \\
\quad(\mathrm{HB})\end{array}$} \\
\hline & $\mathrm{Al}$ & $\mathrm{V}$ & $\mathrm{C}$ & $\mathrm{Fe}$ & 0 & $\mathrm{~N}$ & $\mathrm{~S}$ & REM & $\mathrm{Ti}$ & \\
\hline $\mathrm{T} 2-\mathrm{F}$ & - & - & 0.010 & 0.03 & 0.12 & 0.012 & 0.20 & 0.56 & bal. & 152 \\
\hline $\mathrm{T} 2$ & - & - & 0.014 & 0.05 & 0.12 & 0.012 & - & - & bal. & 154 \\
\hline T4-F & - & - & 0.016 & 0.09 & 0.31 & 0.017 & 0.22 & 0.86 & bal. & 235 \\
\hline $\mathrm{T} 4$ & - & - & 0.011 & 0.09 & 0.32 & 0.007 & - & - & bal. & 233 \\
\hline $3-2-F$ & 3.24 & 2.07 & 0.017 & 0.14 & 0.15 & 0.008 & 0.22 & 0.88 & bal. & 266 \\
\hline $3-2$ & 3.32 & 2.13 & 0.013 & 0.14 & 0.16 & 0.018 & - & - & bal. & 255 \\
\hline $6-4-F$ & 5.96 & 3.92 & 0.008 & 0.19 & 0.12 & 0.004 & 0.16 & 0.46 & bal. & 330 \\
\hline $6-4$ & 6.01 & 4.05 & 0.010 & 0.14 & 0.16 & 0.011 & - & - & bal. & 338 \\
\hline
\end{tabular}

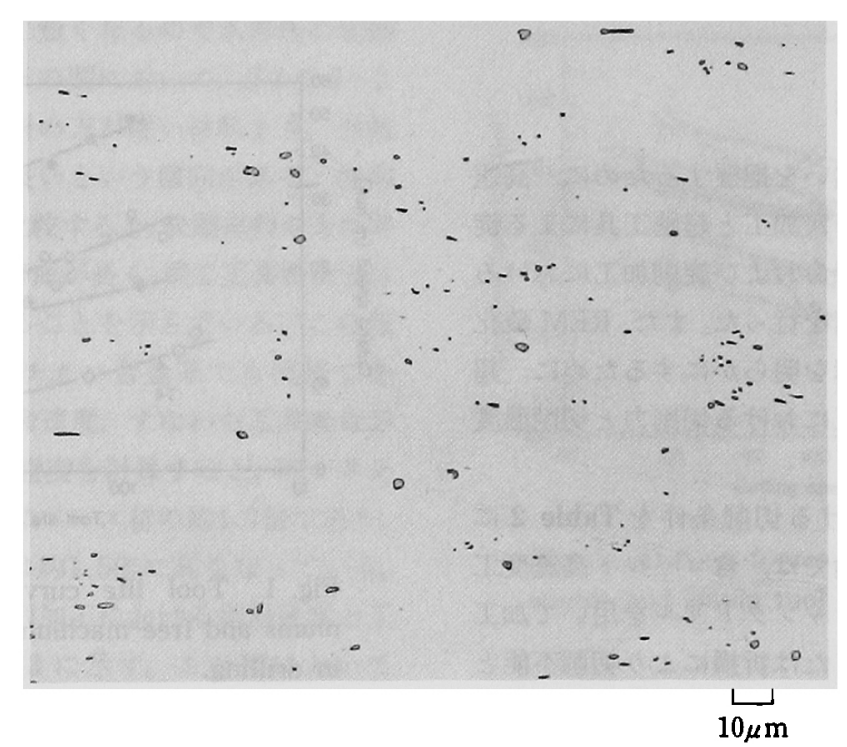

Photo.1. Sulfide inclusions of T2-F.

にFを付けて区別している。快削材料の製造にお いて, REM の原料として, Ce 含有量 $47 \%, \mathrm{La}$ 含 有量 $27 \%$ ，その他の希土類金属総含有量 $26 \%$ の合 金であるミッシュメタルを用いたので，同表の REM 含有量はこれらの元素の総量で示してあ る。

Table 1 の成分が得られるよらにあらかじめ調 合した原料を用いて，溶解量 $100 \mathrm{~kg}$ のプラズマ皘 㬝凝固炉にて一次溶解を行った。そのインジット を消耗電極として，真空フーク炉により二次溶解 を行った。このようにして製造した直径 $240 \mathrm{~mm}$
のインゴットを，約 $1100^{\circ} \mathrm{C} に$ 加熱し，直径 $60 \mathrm{~mm}$ の丸棒に鍛造した。その後, $705^{\circ} \mathrm{C} て ゙$ 焼なまし処理 を行った。焼なまし処理後の硬さを Table 1 の右 端に示した。純チタン 2 種が最も軟らかく, $6 \mathrm{Al}$ $-4 \mathrm{~V}$ 合金が最も硬い。純チタン 4 種と $3 \mathrm{Al}-2 \mathrm{~V}$ 合 金は近い值を示している。

Photo. 1 K快削純チタン T2-Fの介在物の例 を示す。これらの介在物は REM の硫化物である ことをEPMAで確認している。硫化物の大きさ は $5 \mu$ 以下であり，通常の硫黄快削鋼の硫化物に 比べると微細である。 
Table 2. Cutting conditions in machinability tests.

\begin{tabular}{l|l|l}
\hline Item & Drilling & Turning \\
\hline Tool & $\begin{array}{l}\text { Co-HSS (SKH56eq.) } \\
\phi 5 \mathrm{~mm}\end{array}$ & $\begin{array}{l}\text { K10,(5,5,6,6,30,0,0.4) } \\
\text { [tool life, chip br.] } \\
\text { K10,(0,5,6,6,6,0,0) } \\
\text { [force, temp.] }\end{array}$ \\
\hline Feed (mm/rev) & 0.07 & 0.15, var.[chip br.] \\
\hline Depth of cut (mm) & 15 (blind) & 1.0, var.[chip br.] \\
\hline Speed (m/min) & $8 \sim 49$ & $45 \sim 200,60[$ chip br.] \\
\hline Cutting fluid & $\begin{array}{l}\text { non [pure Ti] } \\
\text { water soluble oil } \\
{[\text { alloy] }}\end{array}$ & non \\
\hline Tool life criterion & Tool failure & Crater wear $=0.05 \mathrm{~mm}$ \\
\hline
\end{tabular}

\section{3. 切削試験方法}

材種間の被削性の違いを把握するために，高速 度工具鋼ドリルによる穴加工と超硬工具による旋 削加工における工具寿命および旋削加工における 切りくず破碎性の評価を行った。また, REM 硫化 物の被削性改善の機構を明らかにするために，超 硬工具による旋削加工における切削力と切削温度 の測定を行った。

これらの試験における切削条件を Table 2 に 示す。ドリル寿命試験では, 含コバルト高速度工 具鋼製のストレートシャンクドリルを用いて加工 を行い，工具が溶損または折損により切削不能と なるまでに加工した穴深さの総計を求めた。旋削 加工に怙いては，チタン系の材料で最も一般的に 使用されている超硬合金K10種のスローアウェイ 工具を用いた。工具寿命はクレータ摩耗の深さが $0.05 \mathrm{~mm}$ になる時間とした。切りくず破砝性の評 価試験では，チップブレーカの無い工具を使用し て数秒間切削加工を行い，得られた切りくずを破 砕切りくずと連続切りくずに分類した ${ }^{2)}$ 。切削力 は切削動力系を用いて測定し，切削温度は切りく ずー工具熱電対法を用いて測定した。

\section{4. 試 験 結 果}

ドリル加エに括ける切削速度と工具寿命の関係 をFig. 1 と Fig. 2 に示す。Fig. 1 の純チタン系材 料については，切削油剤を用いずに乾式切削で試

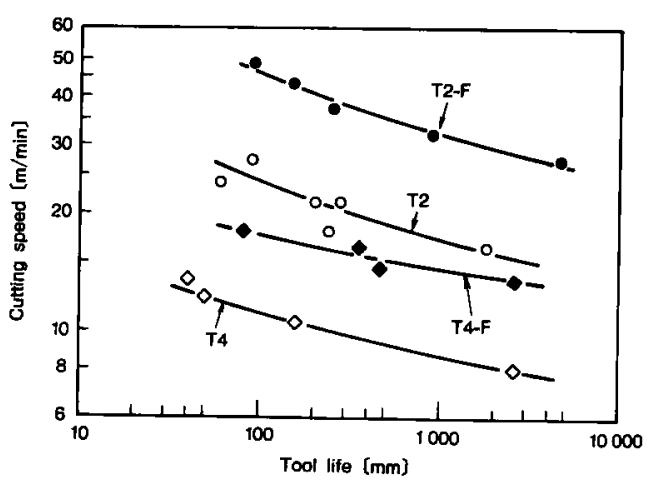

Fig. 1. Tool life curves of pure titaniums and free-machining pure titaniums in drilling.

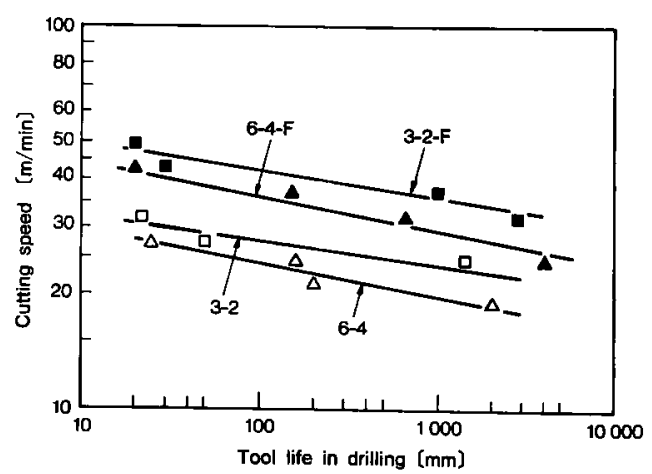

Fig. 2. Tool life curves of titanium alloys and free-machining titanium alloys in drilling. 


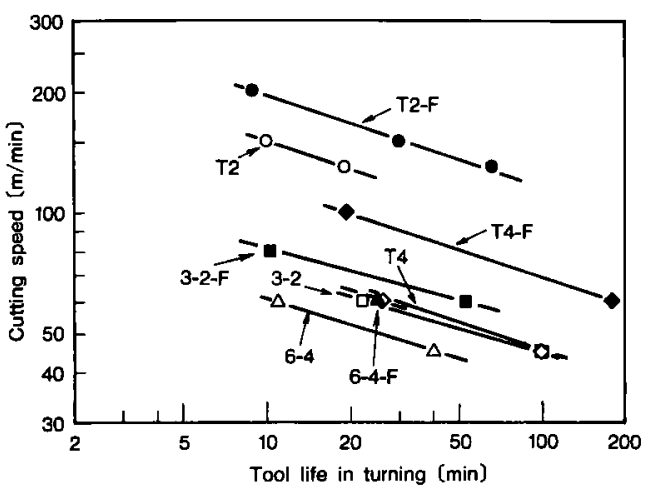

Fig. 3. Tool life curves in turning.

験を行ったが, Fig. 2 のタン合金系材料につい ては工具寿命が著しく短くなるので水溶性の切削 油剂を使用した。各々の図に拈いて，T2ゃ 3-2 のよらに軟らかい材料の方が硬い材料より，当然 ながら，工具寿命が長いという傾向がある。快削 材料とべース材料を比較すると, 快削材料の方が同 じ切削速度でる工具寿命が長く，同じ工具寿命では より高速で加工できることを示している。この傾 向は純チタン系ですチタン合金系でも同様であ る。 $1000 \mathrm{~mm}$ 工具寿命速度, 寸なわち工具寿命が $1000 \mathrm{~mm}$ になる切削速度を計算すると，純チタン 系の場合，快削材料はベース材の約1.7倍であり， チタン合金系の場合は約 1.5 倍に高くなっている。 超硬工具による旋削加工における切削速度と工 具寿命の関係を Fig. 3 に示す。この図において も，ドリル加工の場合と同様に，軟らかい材料の 方が工具寿命が長いといら傾向が認められる。 $20 \mathrm{~min}$ の工具寿命に対応する切削速度で比較した 場合，快削材料はペース材料に比べて1.2〜1.5倍 に改善されることを示している。

送りと切り込みを变化させて切削した場合の切 りくずについて，破砕切りくずと連続切りくずの 範囲の境界線を Fig. 4 に示す。同図において，実 線あるいは破線の右上方が破砕切りくずの範囲で あり，左下方が連続切りくずの範囲である。4 種 類のベース材料のらち，6-4が最も優れた切りく ず破碎性を有している。これは6-4が鋸歯状の切 りくずを生成しやすい, ${ }^{3,4}$ ということと関係して いる。快削材料はベース材料に比べて破砕切りく ずの得られる範囲が広く，切りくず破砕性に優れ

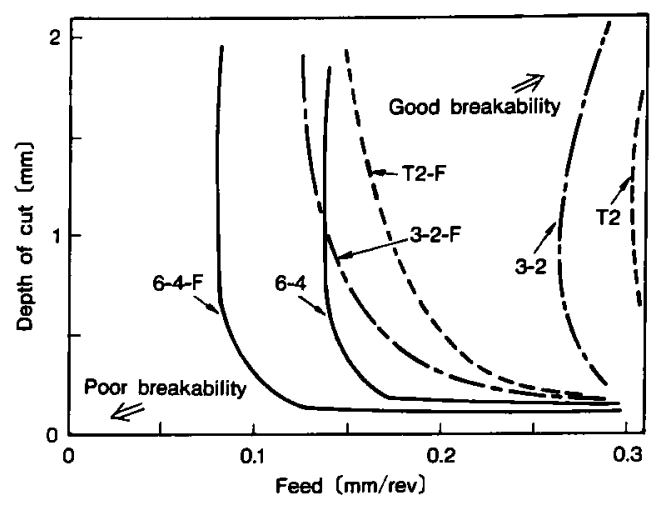

Fig. 4. Comparison of chip breakability of various types of titaniums and tita. nium alloys.

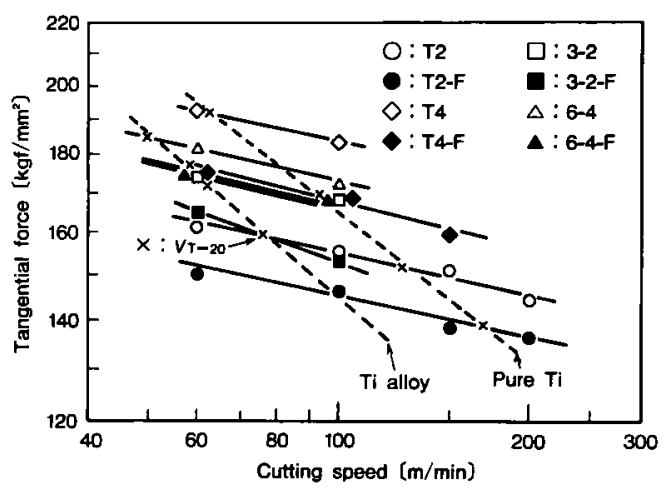

Fig. 5. Cutting forces at various cutting speeds and $20 \mathrm{~min}$ tool life speeds $V_{\mathrm{T}=20}$.

ているが，その改善の程度は，べース材料の切り くず破砕性が劣る T2や3-2で顕著である。

超硬工具による旋削加工時に測定した切削力の $5 ち$ ，主分力（Tangential force）と切削速度の 関係を Fig. 5 に示す。この図は両対数グラフであ るが，どの材料も切削速度の上昇に伴い切削力が ほぼ直線的に低下している。ペース材料間の比較 をすると，T2 の切削力が最も小さく， T4 が最も 高い。硬さの高い6-4 は T4より切削力が低く, 切削力は被削材の硬さと必ずしも対応していな い。快削材料とベース材料の切削力を比較すると， 快削材料の方が 7 - 10\%低くなっている。

切削力の測定の場合と同じ条件下で測定した切 削温度と切削速度の関係を Fig. 6 に示す。切削温 


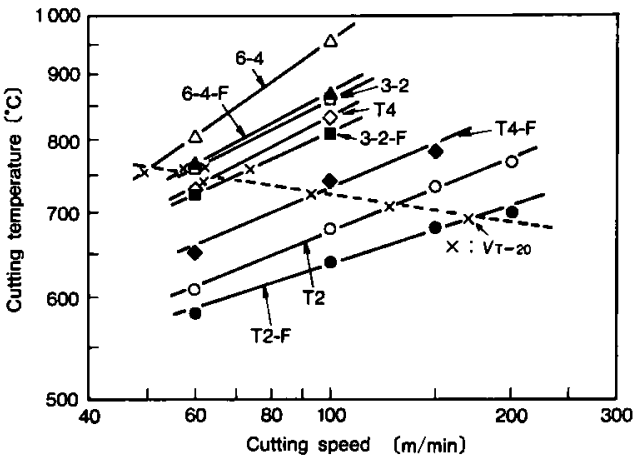

Fig. 6. Cutting temperature at various cutting speeds and $20 \mathrm{~min}$ tool life speeds $V_{\mathrm{r}=\mathbf{2 0}}$.

度は切削速度の上昇に伴い両対数グラフ上でほぼ 直線的に高くなる。ベース材料のなかでは $\mathrm{T} 2$ の 切削温度が最も低く，6-4が最も高い。これは被 削材の硬さとほぼ対応している。快削材料はべー ス材に比へて切削温度が低く，その低下率は 5 〜 10\%の範囲である。

\section{5. 考察}

以下の考察においてて，旋削加工に㧍ける被削 性を表す值として，20分工具寿命速度を用いるこ

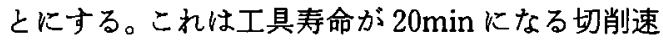
度であり，加工能率といら観点から被削性を表現 している。

Fig. 3 のデータから各々の材料の 20 分工具寿命 速度を計算して, Fig. 5 の切削速度一切削力の関 係を示す直線上にプロットした。8 種頑の試験材 料について20分工具寿命速度の点をつなぐと図中 の破線のよらになり, 純チタンとチタン合金の 2 種類に別れ，各々は直線になる。快削材料とべー ス材料は同し直線上にある。このことは，純チタ ンあるいはチタン合金のなかでは，合金元素の工 具寿命速度に及ぽす影響は切削力と関係してお り，快削元素 (S と REM) の影響も切削力の低下 と対応していることを示している。しかし，純チ タンとチタン合金の工具寿命速度の違いは切削力 では説明できず，これ以外の要因のあることを示 唆している。

Fig. 6 の切削速度一切削温度の関係図にも，同 様に，20分工具寿命速度をブロットした。この場

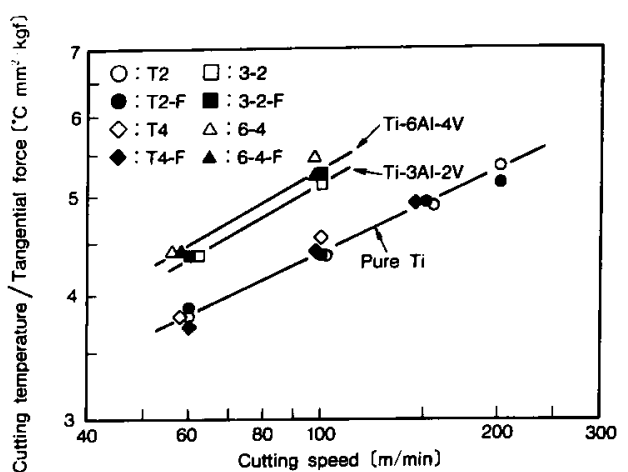

Fig. 7. Ratios of cutting temperature and tangential force at various cutting speeds.

合には，全ての材料のデータが同じ直線上に乗っ ている。しかも，20分工具寿命速度に対応する切 削温度は700 $760^{\circ} \mathrm{C}$ の範围に入っている。一般に, 切削工具の摩耗速度は切削温度のべき関数で表さ れることが知られている5)。Fig. 6 に执いて，種々 の材料の 20 分工具寿命速度と切削温度が注注一定 になっていることは，チタン系材料に打いてもこ の関係が成り立つことを示している。

同図に招いて，快削材料とべース材料の 20 分工 具寿命速度のデータが同じ直線上にあることか ら，Sと REM の複合添加による工具寿命速度の 上昇は，切削温度の低下によっていることを示し ている。Fig. 5 と Fig. 6 の両方を考慮すると，快削 元素の添加により切削抵抗が低下し，その結果， 切削温度が低下して工具摩耗速度が低下するとい ら機構が考兄られる。

Fig. 5 において純チタンとチタン合金の 2 本に 分かれていた関係が，Fig.6では一本の直線にな っていることから，純チタンとチタン合金は切削 力が同じであっても切削温度が異なることがわか る。

切削温度 $\theta$ は, 次元解析と実験データの解析の 結果, 次の式で表されることが知られている5゙。

$\theta / F=\mathrm{C}_{0} V^{2 \mathrm{n}} A^{\mathrm{n}-1} /\left(K^{2 \mathrm{n}} h^{1-2 \mathrm{n}}\right) \quad \cdots \cdots \cdots \cdots(1)$ ここで， $F$ は主分力, $\mathrm{C}_{\mathrm{o}}$ は定数, $V$ は切削速度, $A$ は切削面積（切り込み×送り），Kは熱伝導率, $h$ 住体積比熱(比重 $\times$ 比熱)， $\mathrm{n}$ は指数である。Fig. 5 と Fig.6に示した切削温度と切削力の比を求 め,この比と切削速度の関係を Fig. 7 に示した。 同図において，両対数グラフ上で直線関係にある 
Table 3. Calculation of $K^{2 n} h^{1-2 n}$ in equation (1).

\begin{tabular}{c|c|c|cc}
\hline Grade & $\begin{array}{c}K \\
\mathrm{cal} / \mathrm{cm} / \mathrm{s} / \mathrm{K}\end{array}$ & $\begin{array}{c}h \\
\mathrm{cal} / \mathrm{cm}^{3} / \mathrm{K}\end{array}$ & $1 /\left(K^{2 \mathrm{n}} h^{1-2 \mathrm{n}}\right)$ & [ratio to T2] \\
\hline $\mathrm{T} 2$ & 0.041 & 0.56 & 3.71 & {$[1.0]$} \\
\hline $\mathrm{T} 4$ & 0.042 & 0.58 & 3.60 & {$[0.97]$} \\
\hline $3-2$ & 0.025 & 0.58 & 4.16 & {$[1.12]$} \\
\hline $6-4$ & 0.017 & 0.58 & 4.63 & {$[1.25]$} \\
\hline
\end{tabular}

ことは，本実験においても式(1)の成立することを 示している。切削温度／切削力の比と切削温度の 関係を示す直線が，純チタンとチタン合金で異な っていることの理由として，式(1)は熱伝導率と体 積比熱の違いが影響していることを示唆してい る。切削加工による塑性変形領域の温度は位置に より大きく異なるので，式(1)の熱伝導率や比熱の 值として，どの温度の值を用いるべきかは明らか でないが、ここでは室温の値を用いて計算した。 その結果を Table 3 に示す。指数の $2 \mathrm{n}$ の值は Fig. 7 の直線の傾きから求めた平均値0.28を用い た。式(1)の右辺の分子は定数と切削条件で決まる ので，分母の計算を行った。T2との比率も同表に 示したが、これらの值はFig.7の材種間の比にほ ぼ等しくなって和り，純チタンとチタン合金の切 削温度は材料の熱的性質の違いに起因していると 考えることができる。一方，SとREMを添加して る熱的性質はほとんど变化しないことを確認して いるので，これらの快削元素の添加による被削性 の改善は式(1)の切削力 $F$ の減少に起因すると考兄 られる。

鋼に $\mathrm{S}$ P $\mathrm{Pb}$ などの快削元素を添加すると切削 力が低下するが，その場合には，主分力と送り分 カから計算される工具すくい面上の摩擦俰数む低 下することが知られている6゙。だし，Sの場合に は潤滑作用は無く，脆化作用が主たる機構である という報告もある゙。本実験で得られたデータか ら，単一せん断面理論を用い，工具すくい面上の 垂直力と摩擦力を計算して, 両者の関係をプロッ トすると Fig. 8 のよ5になる。この図において， 原点方向に引いた直線は摩擦係数一定でせん断応 力が減少する場合の垂直力と摩擦力の変化を示し ている。一方，斜め左下方向の矢印はせん断応力 一定で摩擦係数が減少する場合の変化である。快

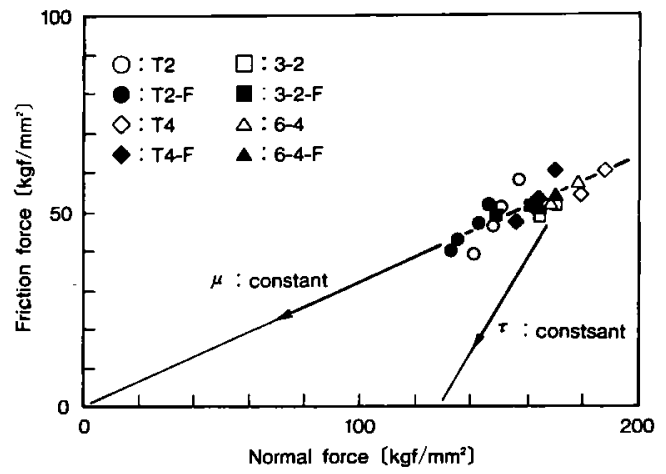

Fig. 8. Relationship between normal force and friction force on tool rake face in turning.

削鋼の場合には，後者の方向に変化することが多 (2)。純チタンやチタン合金にSとREM を添加 しても，摩擦俰数はほとんど変化せずに，せん断 応力の減少する方向に変化していることがわか る。

Photo. 2 に快削純チタンと純チタンの切りく ずの断面を示す。どちらも鋸曾状の切りくずにな っているが, 快削純子タンの方がその程度が強く, 切りくず生成の平均塑性変形量の少ないことを意 味している9)。したがって，SとREM の添加によ り生成した介在物は，鋸歯状切りくずの集中すへ り面の変形を容易にすることによって，切削抵抗 を減少するといら機構が考占られる。チタン合金 の場合にも同様の傾向が認められる。また，快削 材料が鋸歯状切りくず生成傾向の強いことは, 前 述の切りくず破砕性の優れていることの原因であ ると考えられる。 

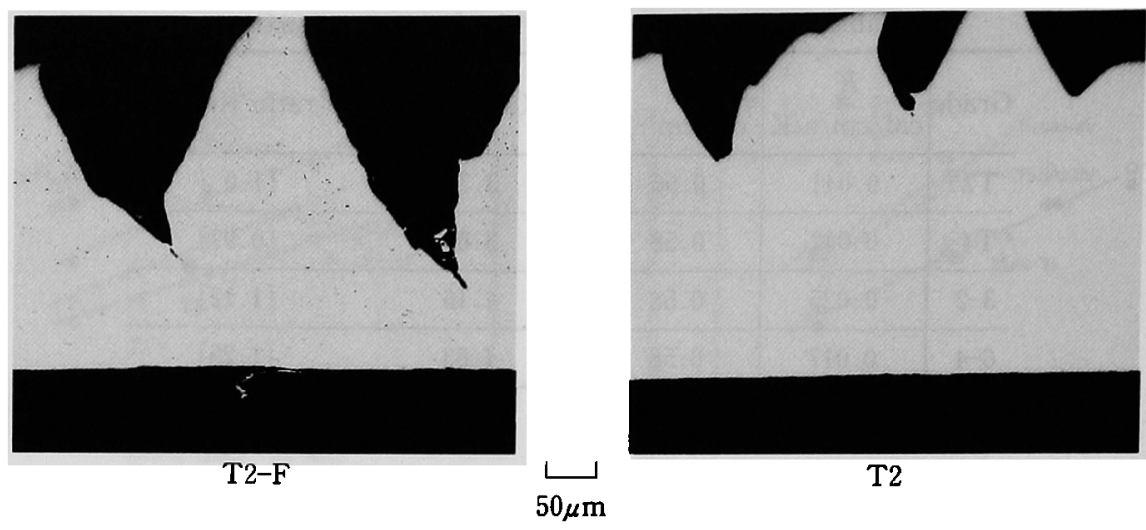

Photo. 2. Cross-section of typical chips.

\section{6. 結}

論

純チタン 2 種および 4 種と， $3 \mathrm{Al}-2 \mathrm{~V}$ 合金およ び $6 \mathrm{Al}-4 \mathrm{~V}$ 合金に S と REM を添加した快削純 チタンと快削チタン合金に関して，その被削性の 評価と，被削性改善の機構に関する検討を行い， 次のことが明らかになった。

(1) 純チタンとチタン合金に S と REM を添加 することにより，ドリル加工および超硬工具によ る旋削加工において工具寿命が改善される。

（2）純チタンとチタン合金の工具寿命あるいは 工具寿命速度は切削力と必ずしも対応して扣ら ず，切削温度と対応している。純チタンとチタン 合金の被削性の差は，その熱伝導率や体積比熱な ど熱的性質の差に起因している。

(3) S と REM 添加により生成した硫化物は鋸 曾状の切りくずの生成㑯向を高める作用があり， このために快削材料はべース材料に比べて切削力 が小さく，その結果，切削温度が低下し，工具寿 命が改善されるという機構が考えられる。

（4）快削純チタンと快削チタン合金はともにぺ ース材より切りくずの破砕性に優れている。これ
あ鋸菌状切りくずの発達に起因するものと考えら れる。

\section{（文 献）}

1）中村貞行：電気製鋼，59（1988）2，79

2) S. Nakamura, J. D. Christopher and G. J. Wuebbling : Tech. Paper of SME, MR82 -235 (1982)

3) R. Komanduri and B. F, von Turkovich : Wear, 69 (1981), 179

4) E. Usui, T. Obikawa and T. Shirakashi : Proc. 5th Int. Conf. Prod. Eng., Tokyo, JSPE, (1984), 233

5) M. Kronenberg: "Machining Science and Application", Pergamon Press, (1966)

6）山口勝美：電気製鋼，49（1978）3，139

7）曰井英治：機械試験所報告第43号，(1961）

8）阿部山尚三，木村篤良，中村貞行：電気製鋼， 55 (1984) 3， 177

9）上田 昇，松尾哲夫：精密機械，44（1978） 9, 1085 